\title{
EVALUATION OF BALADY BREAD CHARACTERISTICS PREPARED FROM WHEAT FLOUR FORTIFIED WITH TWO DIFFERENT IRON FORTIFICANTS
}

\author{
BEDEIR, SALAH H.
}

Food Tech. Res. Ins., ARC, Giza, Egypt.

(Manuscript received 31 July 2013)

\begin{abstract}
Iron can be added to flour to replace what is lost from iron during milling or to reach a level higher than naturally found in the whole wheat, which is known as fortification. The criteria for selecting the form of iron to add as fortificant include the effect on the quality of the flour and bread, and the cost.

Due to the advantages of iron - amino acid chelate, as organic form, its high bioavailability and its ability to protect the iron from binding with phenols and phytic acid and its resistance to stomach acidity and high temperature of food processing beside its safety, it may be preferred in bread making than iron in its an inorganic form.

Therefore, this study was carried out to compare between two wheat flour fortificants, organic form iron (as iron bis- glycinate) and ferrous sulphate (as inorganic form) to prepare balady bread under Egyptian conditions.

Physical, chemical, rheological and organoleptic characteristics of the resulted balady bread were evaluated and the resulted data were statistically analysis. The results showed that increasing the level of ferrous addition (organic or inorganic forms) led to an increase in gluten index. It also, was found that no significant differences were observed between control sample (unfortified) and the two fortificants flour samples in all farinograph measurements such as: water absorption (\%), arrival time, and dough development time and dough stability. Cost of iron also, fortification for one ton of wheat flour was calculated, in order to encouragement the official authorities such as Ministry of Supply and Internal Trade and Milling Companies. It also aimed to spread the knowledge of wheat flour fortification, which led to obtain a high nutritional value of balady bread.
\end{abstract}

Key words: Fortification, Ferrous biglycinate, balady bread, Rheological properties - Iron deficiency.

\section{INTRODUCTION}

Iron deficiency in human nutrition is a result of the insufficient amount of the absorbed dietary iron in relation to the iron requirement. More than 2.5 billion people, especially women and children, around all the world, are Iron Deficiency Anemia (IDA) cases and about $30-60 \%$ of women and children in developing countries are affected by this disorder and much larger numbers are considered as iron deficiency without anemia (FAO/ILSI, 2001). 
In Egypt, recent surveys showed that there are large numbers of individuals who are anemic. Preliminary dietary information indicates that both the quantity of iron in the diet and the bioavailability of such iron form are the main reasons which let a number of individuals to have low iron stores (Bloksma and Bushuk 1988).

Iron deficiency situation is more common when iron requirements are higher, and could not overcome the blood losses happened due to some physiological status, for instances, during pregnancy and growth, which increase the iron loss in some patients, as immense or through some parasitic infections, and in case of bad food habits which lead to impair iron absorption.

It is possible to face the anemia problem through the enrichment of wheat flour with iron. But, many barriers to successful iron fortification is countered due to may reache the over dose risk, affect sensory parameters of bread or inhibitory effects on iron absorption due to phytic acid, phenolic compounds and calcium. It could be successfully to overcome on such barriers by using iron-amino acid chelating compounds (Mohamed 2004).

Many countries are using fortification programmes through voluntary or mandatory legislation. Most of them, fortify their diets with iron and folic acid compounds. Recently, iron fortified flours have been used in different countries of the world including China, Venezuela and other American countries (Sun et al., 2007).

Many international organizations recommended implementing iron fortification process at $60 \mathrm{ppm}$ elemental iron and $1.5 \mathrm{ppm}$ folic acid without affecting the sensory properties either of flour or processed products (Darnton and Hill., 1999).

Food fortification is one of the most cost-effective and sustainable strategies for increasing daily iron intake in populations (Huang et al., 2009).

Several trials reported that the consumption of iron-fortified staple foods or condiments improves iron status. Although the vehicle and fortification compound must be intended chosen because most iron compounds cause discoloration or rancidity (Kovacs, et al., 2004) in the final products. Whereas iron chelates have been extensively tested and shown excellent organoleptic properties, no effects on oxidation and contribute minimal changes in taste as stated by Mazariegos et al., (2004).

Clinical studies on amino acids chelated products (utilize some iron forms such as ferrous bisglycinate, iron amino acid chelate, ... etc.,) showed significant improvements in hemoglobin and ferretine indices at lower dosages than ferrous sulfate or ferrous ascorbate (Viteri, 1998).

The lower dosages term means fewer side effects and no interactions with other nutrients (Mazariegos et al., 2004). 
In a study at the Latin American Center for Nutrition and Metabolic Studies in Antigua, Guatemala, it was found that infants with iron-deficiency anemia given amino acid chelate as supplement or fortificant had significant increases in both hemoglobin and plasma ferretine. It was, also, concluded that chelated iron is the good choice due to its high bioavailability and good regulation (FAO/ILSI, 2001).

Balady bread is an important staple food in Egypt, eaten by almost population besides broad beans dishes and drinking heavy black tea which contains some iron bioavailability inhibitors. Hence, wheat flour is a quite suitable choice for iron fortification (Nalubola and Nestel, 2000).

Other different products (wheat flour, bakery and pastry products, pasta, flakes, cakes and biscuits) are highly consumed by the population. Therefore, wheat products are an excellent support for enriching foods with various nutrients.

One of the main problems of such issue is the absence of the data on the effect of different forms of chelating iron-amino acid on technological and sensory characteristics of Egyptian bread (Balady) under local conditions.

Therefore, the present study is designed to fortify balady bread with two fortificants: inorganic form (ferrous sulphate) and organic form (Ferrous bisglycinate). A comparative study between the utilization of ferrous sulfate in versus of ferrous bis-glycinat in wheat flour is carried out to produce Egyptian bread under local common conditions. An evaluation of balady bread made from wheat flour fortified with the two fortificants in a popular staple food in Egypt, was done to identify the suitable choice for iron fortification.

\section{MATERIALS AND METHODS}

\section{Materials:}

Food grade ferrous sulphate $\left(\mathrm{Fe}\left(\mathrm{SO}_{4}\right)_{2}, 7 \mathrm{H}_{2} \mathrm{O}\right)$ and ferrous bis-glycinate were obtained from Scientific Company for Trading - Cairo - Egypt. The utilized amounts of both materials were according to WHO recommendations (up to $40 \mathrm{mg} / \mathrm{kg}$ wheat flour) as mentioned by Darnton and Hill (1999), and Nalubola and Nestel,(2000).

The milled wheat flour (semi - hard red winter $82 \%$ ext. rate) was obtained from Cairo Co. for Milling and Baking, Cairo, Egypt. Other ingredients (yeast and salt) were purchased from local market. Dough balady bread was prepared at Bread and Pastries Dep., Food Tech. Res. Inst., Agric. Res. Center, Giza, Egypt. The wheat flour(82\% ext. rate) samples were divided into three samples:-

1-Control sample (unfortified wheat flour, $82 \%$ ext.). 
2- Ferrous sulfate molecular formula addition (inorganic form), where $396.92 \mathrm{mg}$ of ferrous sulfate (to exactly equilibrate $30.0 \mathrm{mg}$ ferrous) were added to one $\mathrm{kg}$ wheat flour.

3- Ferrous bis glycinate form (organic form), were $30.0 \mathrm{mg}$ of ferrous sulfate bis glycinate were added to one $\mathrm{kg}$ wheat flour.

\section{Balady bread preparation:}

Balady bread formula (Ingredients based on total flour weight) contents were :Wheat flour(82\%) $100 \%$

Water $60-70 \%$

$1.5 \%$ compressed dry activated yeast.

$1 \%$ salt .

All above ingredients were well mixed, and then the resulted dough was done by the straight dough method, and then was left for one hour to be fermented. The dough was divided into $140 \mathrm{gm}$ pieces and left for $30 \mathrm{~min}$. for proofing, then flatted and oven to diameter about $25 \mathrm{~cm}$, after that the resulted dough loaves were left to take a rest for about $15 \mathrm{~min}$. and finally baked at $450 \circ-500 \circ \mathrm{c}$ for one minute, as described by Khorshid et al., (1982).

Bread samples were cooled enough to room temperature and kept in polyethyline bags till the organoleptic evaluation.

\section{Methods of Analysis:}

\section{1- Chemical analysis:}

Moisture, crude protein, crude fat, fiber and ash contents were determined according to the methods described by AOAC (2004). The total carbohydrates were calculated by differences.

\section{2- Wet and dry gluten:}

Wheat flour gluten contents (wet and dry) and gluten index were determined by Glutomatic 2200 Instrument according to AACC (2002).

\section{3- Falling Number (FN):-}

It was determined according to AACC (2002), Liquefaction Number was calculated as follows:-

Liquefaction Number $=6000 /$ FN- 50

\section{4- Alkaline Water Retention Capacity (AWRC\%) and sedimentation test:}

Such properties were estimated according to AACC (2002).

\section{5- Reological characteristics of dough:-}

The rheological measurements were done by Farinograph (300 B.U), Extinsograph and Visco-amylograph instruments according to AACC (2002). 


\section{6- Organoleptic evaluation:}

Organoleptic evaluation of balady bread was performed by ten panelists at Food Technology Research Institute (FTRI) applying the method described by Peter (2002) and AACC (2002). The scores were depending on the following desired characteristics:-

A - Complete separation of upper and lower layers that are equal in thickness.

B - A soft, moist crumb existence.

$\mathrm{C}-\mathrm{A}$ light shiny crust with brown spots existence.

D - Different sensory attributes such as: crust and crumb texture, color, flavor and overall acceptability.

\section{7- Statistical Analysis}

The obtained results were tabulated and statistically analyzed according to Snedecor and Cochran (1980).

\section{RESULTS AND DISCUSSION}

\section{Wheat flour ( $82 \%$ ext.) composition:-}

Wheat flour was analyzed with respect to moisture, crude protein, fiber, ash, fat, carbohydrates, falling number and liquefaction number. The obtained results shown in Table (1) indicated that moisture, protein, fiber, ash, fat, carbohydrates, falling number and liquefaction number of $82 \%$ ext. wheat flour were $10.59 \%, 12.89 \%$, $1.27 \%, 0.93 \%, 0.48 \%, 84.43, \%, 331 \mathrm{sec}$ and 23 , respectively. Such results were in the same line with that obtained by Kitterman and Barmore (1996). Falling, and liquefaction numbers are indicators of the amylase activity and they should be with the accepted range (more than $260 \mathrm{sec}$., and between 21 - 28 respectively).

Table 1. Composition, falling number and liquefaction number of wheat flour ( $82 \%$ ext.)

\begin{tabular}{|l|l|}
\hline Item & Values \\
\hline Moisture & 10.59 \\
\hline Protein* & 12.89 \\
\hline Fiber* & 1.27 \\
\hline Ash* & 0.93 \\
\hline Fat* & 0.48 \\
\hline Carbohydrates* & 84.43 \\
\hline Falling number** & 331.00 \\
\hline Liquefaction number & 23.00 \\
\hline
\end{tabular}

* As $\%$ on dry weight basis

** Determined in sec. 


\section{Gluten contents and physical properties of the tested dough:}

Gluten contents (wet, dry gluten) and gluten index of the resulted dough considered a very important factor in determining the flour quality. Since, wet gluten represents the ability of gluten to binding water. These phenomena is determined the rheological properties of dough and certainly might affect the baking quality of the processed balady bread (Peter 2002 and Kovacs et al., 2004)

Wet, dry gluten and gluten index of the tested dough (resulted from control and iron fortified wheat flour) are presented in Table (2). Wet gluten and the gluten index of control sample recorded $21.4 \%$, and $91.4 \%$, respectively. It showed that increasing the level of ferrous addition (inorganic or organic forms) led to a slightly increment in both gluten form contents and gluten index.

This means that gluten network goes to be stronger due to increase in the amount of bonds. Such results are in agreement with that obtained by Berlant and Launary (1995) and such criteria were confirmed by farinograph and extensograph parameters such as elasticity which will be discussed later.

Regarding the results presented in Table (2), it could indicated that inorganic and organic iron forms fortificants addition may be change the gluten network to be stronger, highly water absorbability and finally increase the gluten index than in the control sample (unfortified wheat flour).

Results showed that high significant differences were obtained in both organic and inorganic form compared with control sample.

The same model was found in case of sedimentation test of the tested samples .On the other hand, there was a slight increment variation in dry gluten between iron fortified samples, in both forms, from one side and the control sample from the other side. The fortification process led to a slight increase in the dry gluten values than the control sample. The same pattern was also detected with gluten index and Water Binding Capacity (WBC \%) values.

Such results were concurrent with Kitterman and Barmore (1996), who reported that gluten in flour has the ability to absorb moisture and it can forms an elastic, strong and thin structure in dough.

Sedimentation test is also, a physicochemical test could be suggested as a simple means for estimating protein quality as stated by Kovacs et al (2004).

From the obvious results, it could be concluded that a strong positive correlation was existed between the protein content and both sedimentation test and Water Binding Capacity (WBC). This might indicate that not only the quantity of protein but also the quality (gluten- index) has the greatest effect. These conclusions are in agreement with Kitterman and Barmore (1996), who suggested that 
sedimentation test reflected differences in both protein content and gluten quality ( gluten index) and insoluble gluten which are the factors largely responsible for sedimentation and water binding capacity values .

Bomeranz (1988) suggested that wheat flour containing sedimentation values ranging between 20 and $39 \mathrm{~cm} 3$ could be considered suitable for making balady bread, cake or pies.

Table 2 . Wet, dry gluten, gluten index, water binding capacity and sedimentation test of fortified wheat flour ( $82 \%$ ext.) compared with that of unfortified one.

\begin{tabular}{|c|c|c|c|c|c|}
\hline Samples & $\begin{array}{c}\text { Wet gluten } \\
(\%)\end{array}$ & $\begin{array}{c}\text { Dry gluten } \\
(\%)\end{array}$ & $\begin{array}{c}\text { Gluten } \\
\text { index } \\
(\%)\end{array}$ & $\begin{array}{c}\text { Water binding } \\
\text { Capacity } \\
(\%)\end{array}$ & $\begin{array}{c}\text { Sedimentation } \\
\text { test }\left(\mathrm{cm}^{3}\right)\end{array}$ \\
\hline Control* & $21.4 \pm 0.5$ & $7.17 \pm 0.13$ & $91.4 \pm 0.36$ & $14.3 \pm 0.40$ & $25.8 \pm 0.12$ \\
\hline Ferrous sulfate & $22.5 \pm 0.34 * *$ & $7.74 \pm 0.49$ & $93.1 \pm 0.25$ & $14.7 \pm 0.25$ & $26.7 \pm 0.35^{* *}$ \\
\hline Ferrous bis & $22.3 \pm 0.4 * *$ & $7.49 \pm 0.35$ & $92.5 \pm 0.46$ & $14.8 \pm 0.13$ & $26.6 \pm 0.35^{*}$ \\
\hline glycinate & 0.686 & N.S & N.S & N.S & 0.4866 \\
\hline LSD 0.05 & 1.138 & N.S & N.S & N.S & 0.8070 \\
\hline LSD 0.01 & & & & \\
\hline
\end{tabular}

- $\quad$ Each mean value is followed by \pm standard deviation.

*Unfortified wheat flour.

\section{3- Rheological properties :-}

\section{A- Farinograph \&Extensograph parameters:-}

Rheological properties of resulted dough from fortified. wheat flour $82 \%$ ext are tabulated in Table (3).It was found that, no significant differences were observed between control sample and the other two fortified treatments, either organic or inorganic form, in all farinograph measurements such as water absorption (\%), arrival time, dough development time and dough stability.

Whereas, an increase in the degree of softening was found in the organic form. Such result may be due to binding of the amino acid chelating with protein in dough consequently increasing the degree of dough softening.

Improving the charactertics of extinsograph dough measurements were clear by organic form as observed and shown in Table (3).Significant differences between the tested treatments and chelating amino acids were clear in elasticity, extensibility, proportional number and energy, its consistency and elasticity of the dough rises 
which is contrary due to the reducer action of the organic form (Berlant and Launary 1995).

It could be regarded to the role of iron easily binding in the organic than in the inorganic form, consequently improving quality of dough (Mohamed 2004).

\section{B- Visco - Amylograph:-}

Table (4) showed that no significant difference in both maximum viscosity and temperature at maximum viscosity among all the tested treatments, but transition point was affected as a result of chelating between flour starch and iron (Berlant, and Launary1995).

\section{Generally:-}

Iron fortification either by ferrous sulphate (inorganic) or ferrous bis- glycinate (organic) form does not negatively influenced the rheological characteristics of the dough.

Table 3. Rheological characteristics of dough resulted from iron fortified wheat flour (82\% ext.) compared with that of unfortified one.

\begin{tabular}{|c|c|c|c|c|c|c|c|c|c|}
\hline Iron form & \multicolumn{5}{|c|}{ Farinograph } & \multicolumn{4}{|c|}{ Extensograph } \\
\hline Samples & $\begin{array}{c}\text { Water } \\
\text { absorption } \\
(\%)\end{array}$ & $\begin{array}{l}\text { Arrival } \\
\text { time } \\
\text { (min.) }\end{array}$ & $\begin{array}{c}\text { Development } \\
\text { time } \\
\text { (min) }\end{array}$ & $\begin{array}{l}\text { Stablity } \\
\text { (Min) }\end{array}$ & $\begin{array}{c}\text { Degree of } \\
\text { softening } \\
\text { (B.U.) }\end{array}$ & $\begin{array}{c}\text { Elasticity } \\
\text { (B.U.) }\end{array}$ & $\begin{array}{l}\text { Extensibility } \\
(\mathrm{mm})\end{array}$ & $\begin{array}{c}\text { Proportional } \\
\text { Number }\end{array}$ & $\begin{array}{l}\text { Energy } \\
(\mathrm{cm})^{2}\end{array}$ \\
\hline Control* & 50.7 & 1.0 & 1.5 & 7.0 & 65 & 420 & 100 & 4.2 & 33 \\
\hline $\begin{array}{l}\text { Ferrous } \\
\text { sulfate }\end{array}$ & 52.1 & 1.0 & 1.5 & 8.0 & 65 & 440 & 95 & 4.6 & 36 \\
\hline $\begin{array}{l}\text { Ferrous bis } \\
\text { glycinate }\end{array}$ & 51.5 & 1.0 & 1.5 & 7.0 & $80 * *$ & $545^{* *}$ & $130^{* *}$ & 4.2 & 41 \\
\hline L.S.D. 0.05 & N.S & N.S & N.S & N.S & 0.448 & 0.446 & 0.560 & N.S & 0.667 \\
\hline L.S.D.0.01 & N.S & N.S & N.S & N.S & 0.890 & 0.957 & 0.864 & N.S & 0.887 \\
\hline
\end{tabular}

*Unfortified wheat flour.

Table 4. Visco - Amylograph of dough resulted from fortified wheat flour ( $82 \%$ ext.) compared with that of unfortified one.

\begin{tabular}{|c|c|c|c|}
\hline Samples & $\begin{array}{c}\text { Transition } \\
\text { point }\left({ }^{0} \mathrm{C}\right)\end{array}$ & $\begin{array}{c}\text { Max. } \\
\text { viscosity } \\
\text { (B.U.) }\end{array}$ & Temp. at max. viscosity $\left({ }^{0} \mathrm{C}\right)$ \\
\hline Control & $21 . \pm 0.5$ & $71.7 \pm 0.13$ & $92.2 \pm 0.36$ \\
\hline Ferrous sulfate & $22.5 \pm 0.34$ & $77.4 \pm 0.49$ & $93.1 \pm 0.25$ \\
\hline Ferrous bis glycinate & $22.3 \pm 0.4$ & $74.9 \pm 0.35$ & $92.5 \pm 0.46$ \\
\hline L.S.D.0.05 & 0.686 & N.S & N.S \\
\hline L.S.D.0.01 & 1.138 & N.S & N.S \\
\hline
\end{tabular}




\section{Sensory Charactertics of produced balady bread :-}

From the results in Table (5), it could be concluded that there was no differences between control sample and other two treated samples in both crust color, crumb texture, while, there was a significant difference in other characteristics such as: crust quality, loaf raising, crumb color, odor, taste and overall acceptability, but the scores still remained in acceptable range.

The taste of balady bread prepared from unfortified flour (control) and from ferrous bis - glycinate (organic form) got maximum scores for taste, while, samples prepared from ferrous sulfate (inorganic form) got low score for taste.

Finally, it can be observed that balady bread samples treated with ferrous bisglycinate (organic form) gave overall acceptability score as control sample. The bread staling will be related and the resulting bread becomes more freshness than the control sample, the shelf life will be extended. Only, ferrous sulfate, (inorganic form) influences the taste, and the color of balady bread as reported by Huang, et al (2009).

\section{Generally:-}

Sensory study of the iron fortified balady bread revealed that the flour fortified with ferrous bis - glycinate (Organic form) is the better choice for organoleptically acceptability than ferrous sulfate (inorganic) fortified balady bread.

Table 5. Organoleptic Evaluation of fortified balady bread compared with that of unfortified one.

\begin{tabular}{|c|c|c|c|c|c|c|c|c|}
\hline Treatments & $\begin{array}{c}\text { Crust } \\
\text { color }\end{array}$ & $\begin{array}{c}\text { Crust } \\
\text { quality }\end{array}$ & $\begin{array}{c}\text { Loaf } \\
\text { raising }\end{array}$ & $\begin{array}{c}\text { Crumb } \\
\text { Color }\end{array}$ & $\begin{array}{c}\text { Crumb } \\
\text { texture }\end{array}$ & Odor & Taste & $\begin{array}{c}\text { Overall } \\
\text { Accept } \\
\text { ability }\end{array}$ \\
\hline Control* & $8.8 \mathrm{a}$ & $9.7 \mathrm{a}$ & $18.5 \mathrm{a}$ & $13.7 \mathrm{a}$ & $14.8 \mathrm{~b}$ & $14.9 \mathrm{a}$ & $14.9 \mathrm{a}$ & $95.3 \mathrm{a}$ \\
\hline Ferrous sulfate & $8.4 \mathrm{a}$ & $8.6 \mathrm{~b}$ & $17.9 \mathrm{ab}$ & $11.2 \mathrm{ab}$ & $14.2 \mathrm{~b}$ & $13.8 \mathrm{a}$ & $13.9 \mathrm{ab}$ & $88.0 \mathrm{~b}$ \\
$\mathrm{~b}$ & $8.9 \mathrm{a}$ & $9.8 \mathrm{a}$ & $18.6 \mathrm{a}$ & $12.7 \mathrm{a}$ & $14.6 \mathrm{~b}$ & $14.8 \mathrm{a}$ & $15.0 \mathrm{a}$ & $94.4 \mathrm{a}$ \\
\hline $\begin{array}{c}\text { Ferrous bis } \\
\text { glycinate }\end{array}$ & & & & & & & & \\
\hline
\end{tabular}

*Unfortified wheat flour.

Each value within the same column, followed by the same letter is not significant different at 0.05 level. 


\section{Cost of iron fortification :-}

There is approximately 9.0 million Metric Ton of wheat milled into flour each year in Egypt. Most of this quantity is milled in 150 governments controlled mills which produce $90-95 \%$ of $82 \%$ ext. wheat flour quantity produced in Egypt. The technology of modifying flour mills to enable them to produce iron fortified flour is simple and inexpensive.

Each mill has a feeder installed at a position near the end of the mill plant, and the feeder is used to add a premixed iron source to the flour before packaging.

Cost analysis for addition of iron as ferrous bis - glycinate based on providing 30 milligrams of iron per kilogram flour. This equivalent to supplying 85 million people in Egypt with 20-30 milligrams of iron per person per day.

Total costs for fortified one metric ton wheat flour $82 \%$.or $72 \%$ ext. with $30 \mathrm{~g}$. Ferrous with as follows :-

1- Cost per one kg Ferrous bis - glycinate $=84.30$ Egyptian pound.

2- Indirect costs packaging - processing and transport $=28 \%$ of costs $=84.30 \mathrm{x}$ $28 \%=23.60$ Egyptian pound.

3- Total cost for one kg Ferrous bis - glycinate $=84.30+23.6=107.90$ Egyptian pound.

Each one Ton wheat flour need 300gr. Ferrous bis - glycinate $=30 \times 107.90=$ 3.237 Egyptian pound.

\section{General discussion and conclusion:}

Physical characters of dough or bread resulted from iron fortified wheat flour mainly depend on protein quantity and quality. It is generally believed that rheological properties of dough play an important role in covering the quality of bread or baked products (Bloksma and Bushuk 1988).

The proposed work support addition of iron salt directly to wheat flour during milling and aimed to avoid the disadvantages of iron fortified wheat flour in lipids, vitamins $A$ and $C$ then change the flavor and scores due to storage especially at high temperature. (Baltussen, et al., 2004).

Using of suitable iron concentration as $30 \mathrm{mg} / \mathrm{kg}$ either as organic form or ingornic form did not affect the quality of resulted balady bread from fortified wheat flour. As previously mentioned the recommended dose by international organizations is $60 \mathrm{mg} / \mathrm{kg}$ (Darnton and Hill 1999).

Whereas, it is advised to use $30 \mathrm{mg} / \mathrm{kg}$ to avoid the possibilities of over dose toxicity which may be happened due to eating more than three loaves of bread daily as done by common people. 


\section{REFERENCES}

1. AACC. 2002. Approval Method of American Association of Cereal Chemical publ. by American Association of Cereal Chemists, St. Paul, Minnesota, USA.

2. AOAC. 2004. Association of Official Analytical Chemists. Official Methods of Analysis $18^{\text {th }}$ Ed, Washington D.C, USA.

3. Baltussen, R., Knai, C. and Sharan, M. 2004. Iron fortification are costeffective interventions to reduce iron deficiency in four sub regions of the world. J Nutr. 134: $2678-2684$.

4. Berlant,S. and Launary, B. 1995. Rheological properties of wheat flour dough in steady and dynamic shear: Effect of water - content and some additives. Cereal Chem., 72:48-52.

5. Bloksma, M., and Bushuk, E. 1988. Iron bioavailability in humans from breakfasts enriched with iron bis-glycine chelate, phytates and polyphenols. J. Nutr., 130: 2195-2199.

6. Bomeranz, Y. 1988. Wheat: Chemistry and Technology. American Association of Cereal Chem. St. Paul. USA.

7. Darnton, T., and Hill, R. 1999. Vitamin D Status on Saudi Arabia. Proceedings of Workshop on Prevention and Control of Micronutrients Deficiencies in the Arab Gulf Cooperation Council Countries - Riyadh (2- 4 June).

8. FAO/ILSI. 2001. Preventing Micronutrient Malnutrition. A Guide to Food Based Approach. ILSI, Washington, D.C., USA.

9. Huang, J., Li, WX., Wang, L., Wang, AX., Huo, JS., and Chen, JS. 2009. Efficacy of different iron fortificants in wheat flour in controlling iron deficiency. Biomed Apr.,22(2):118-121.

10. Kitterman, J.,S. and Barmore, M.A. 1996. Protein, ash, viscosity, and damaged starch relations in the sedimentation test. Cereal Chem., 64:281286.

11. Khorishid,A.M., EL- Farra,A.A., and Galal, A. N. 1982. Studies on the possibility of supplementation of balady bread with various commercial soyproducts.1th Egypt. Conf. on Bread Res. Pp.9-23.

12. Kovacs, O., Bot, A. and Bruigne, D.W. 2004. Osmotic properties of gluten. Cereal Chem., 80:404-408.

13. Mazariegos, D. I., Pizarro, F., Olivares, M, N. and Arredondo, M. 2004. The Mechanisms for Regulating Absorption of Fe bis-glycine Chelate and Fe Ascorbate in Caco-2 Cells Are Similar, American Society for Nutritional Sciences, 4, 395-398. 
14. Mohamed, O. 2004. Technological aspects of flour enrichment with iron.Acta Univ.CIB. Series E, 8, (1), 112 - 118.

15. Nalubola, R. and Nestel, P. 2000. USAID. manual for wheat flour fortification with iron Technical and operational guidelines Part 2, October 2000.

16. Peter, D., E, (2002). Fortification of curry powder with NaFe (ய) EDTA: report of iron fortification trial. AM.J.Clin.49:162-169.

17. Snedecor and Cochran, (1980). Statistical methods $6^{\text {th }}$ ed. Iowa State Univ.Press. Ames. Iowa. USA.

18. Sun, J., Huang, J., and Li, W. (2007). Effects of wheat flour fortified with different iron fortificants on iron status and anemia prevalence in irondeficient anemic students in Northern China. Asia Pac J Clin Nutr.,16:116-21.

19. Viteri, F. E. 1998. Fortification of flour to control micronutrient deficiencies in countries of the Eastern Mediterranean, Middle East and North Africa. Based on a joint WHO/UNICEF/MI workshop, held in Beirut, Lebanon, 13-16 June 1998. 


\title{
تقييم خصائص الخبز البلاى المصنوع من الدقيق المدعم بنوعين مختلفين من الحديا
}

\author{
صلاح حمزه محمد بدير \\ معرة بحوث تكنولوجيا الاغذية - مركز البحوث النرراعية - الجبزة - مصر
}

تشير العديد من الدراسات الى انه من الممكن اضافة الحديد الى دقيق القمح لتعويض الفقد الذى يحدث فى محتوى الدقيق من الحديد خلال مر احل طحن القمح المختلفة بغرض الوصول الى المستوى المطلوب طبقا للتوصيات و التشريعات الغذائية المحددة لمحتوى الدقيق من العناصر المعدنية وخاصة الحديد ،وتعرف تلك الاضافة بالتدعيم و وتعتمد عملية تدعيم الدقيق على جودة الاقيق المطحون و الخبز الناتج منه وتكلفة التدعيم تبعا لنوعية الحديد المطلوب اضافته . ونظر المميزات الحديد المرتبط بالحامض الاميني الجليسين ( الصورة العضوية) و التى تتشمل قدرته على حماية الحديد من الارتباط بالمو اد الفينولية وحامض الفيتيك ومقاومته لكلا من حموضة الفيات المعدة و ارتفاع درجة حرارة الخبيز العالية المستخدمة فى تصنيع منتجات المخابز ومنها الخبز البلدى الى جانب الامان الكامل له وعدم تسببه لاية اضر ار جانبية، لذلك ربما يفضل استخدام الحديد فى الصورة العضوية فى تكعيم منتجات المخابز مقارنة بالحديد المضاف للدقيق فى صورة كبرة كبريتات الحديدوز (الصورة الغير عضوية).

وقد اجريت تلك الدر اسة باستخدام الحديد فى كلا من الصورة العضوية والصورة الصورة غير العضوية فى تدعيم دقيق القمح استخلاص 82\% المستخدم فى تصنيع الخبز البلدى طبقا للمو اصفات القياسية

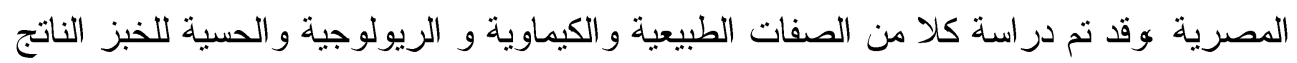
مصحوبة بالتحليل الاحصائى لها و التى اظهرت زيادة معامل جودة الجلوتين للاقيق المدعم بالحديد

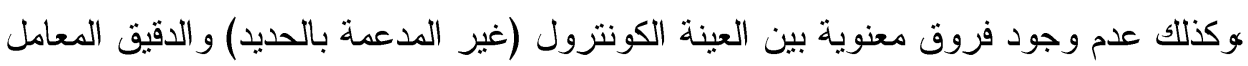

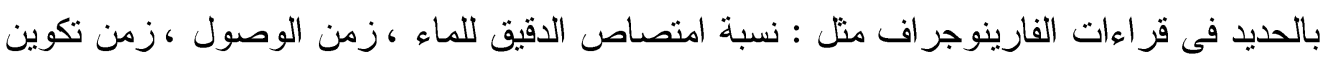

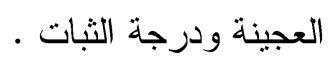

تم ايضا حساب تكلفة تدعيم طن دقيق القمح بالحديد لتشجيع الجهات الرسمية مثل وزارة التموين و التجارة الداخلية والمطاحن وكذللك تهدف الدراسة الى العمل على نشر ثقافة تعزيز الدقيق بالحديد لما له من ايجابيات تغذوية كثيرة على الخبز البلدى الناتج. 